\title{
実装基板における電気検査の動向
}

\author{
大久保 今朝秀*
}

\section{Trends of Electric Inspection for PWBA}

Kesahide OHKUBO*

*日本フェンオール株式会社 PWBA 第二営業部（１ 192-0001＼cjkstart東京都八王子市戸吹町 232）

*FENWAL CONTROLS OF JAPAN, Ltd. PWBA SALES DEPT (232, Tobukicho, Hachioji-shi, Tokyo 192-0001)

\section{1. はじめに}

近年, スマートホンを代表とする電子機器の小型化と多 機能化に伴い, 半導体やプリント配線板の高集積化・高密 度化がますます加速している。

また一方では，製品の信頼性をより向上させるため，開 発から製造までの各現場では製品の製造や検査にさまざま な工夫や改善を取り入れ顧客のニーズに対応しているのが 現状である。

特に実装基板の電気検査では多くの場合, プローブピン やコネクタなどで実際の基板にコンタクト（接触）をする 必要があるが上述のような背景で「見えない・触れない」 テスト対象を取り扱う頻度が増している。

本稿では, 実装基板の生産数量と信頼度要求レベルの違 いから求められる, 最近の実装基板の電気検査の動向につ いて一部の事例を紹介しながら述べる。

\section{2. 実装基板の品質保証}

\section{1 まえがき}

電子機器の製品出荷時には, 機器・システムの価格・用 途・信頼性要求レベルに関わらずどの製品でも完成品とし ての動作試験（システム検査）が行われる。
これらの製品に組み込まれる実装基板は，製品完成後の システム検査の前に，実装基板の状態でも外観検査や電気 検査を行い品質保証している。

実装基板の電気検査は主に, (1)部品の故障や部品実装上 の不具合（接続部のオープン・ショート, 部品搭載の誤り) の検査と，(2)実装基板の持つべき機能検査とに分かれる。 前者の検査を担うのがインサーキットテスト（以下 ICT）お よびバウンダリスキャンテストであり，後者の検査はファ ンクションテスト（以下FCT）と呼ばれる。通常 ICT で実 装基板の構造上の不良の有無を検出してから FCT を行うの が良いとされ，ICT と FCT を兼ねたテスタも市販されてい る。

しかし ICT・FCT のいずれも今日，テストの有効性が大 きく低下してきている。こうした状況から装置メーカでは 装置の要素である実装基板に対して，設計工程からの品質 の作り込みに取り組む動きが多い。

図 1 にそれらの取り組みの概要を示す。具体的には，装 置のシステム設計の段階から，その製品に対する製造現場 での製品作りのノウハウや検査手法をレビューし，設計段 階から考慮すべき事項を確認する。同時に設計者は，製造 方法や検查方法に対する理解を深め, 以降の設計段階でも 新たな課題に気づいた場合，直ちに対処できるような体制

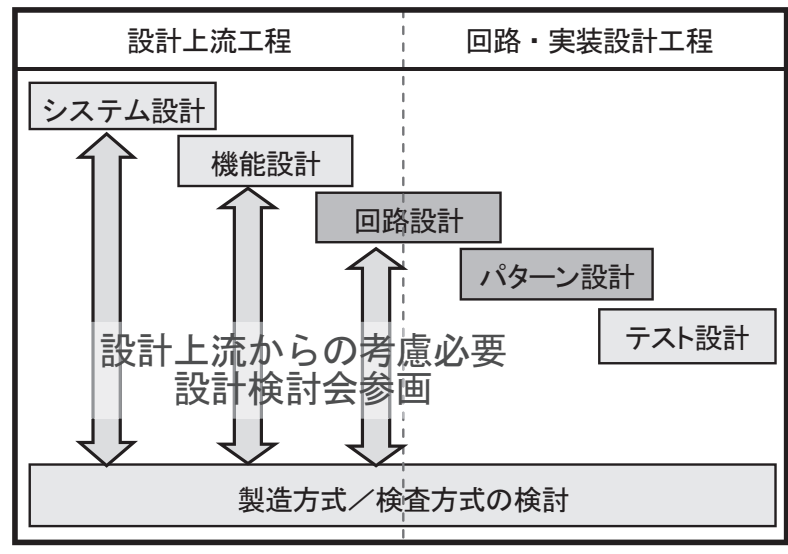

図 1. 上流設計工程での製造・検査品質の作り込み 
を作っておく必要がある ${ }^{3)} 。$

\section{2 試験方式の説明}

\subsubsection{ICT}

ICT では回路のノードにテストプローブを当てて部品単 位，ネット単位でテストするのが基本であるが, 昨今, BGA どのプロービング出来ない部品が増えてきたため, ICT のテストカバレージが大きく低下してきている。

インサーキットテスタには, テスト用の信号を基板に与 えたり観測したりするためのプローブピンをテスト治具に 固定してテストをするテスト治具方式と, 数本のプローブ ピンを移動させてテストをする，フライングプローブ方式 がある2)。

図 2 は，テストジグ方式のインサーキットテスタであ る。検查するポイントに固定式のプローブが設けられてい る。検查ポイントの切り替えはリレーまたは半導体スイッ チを用いて電気的に行われるため, 高速にテストができる という利点がある。しかし，テストジグを作成する期間が かかる，テストジグ費が高い，テストジグ保管抒よびメン テナンスオーバヘッドが大きいなどの欠点がある。

図 3 は, フライングプローブ方式インサーキットテスタ である。検査プログラムにより基板上の任意の場所にプ

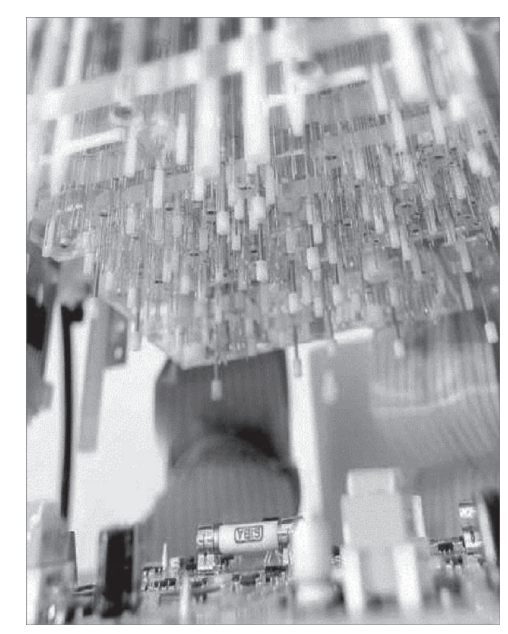

図 2. テスト治具式のインサーキットテスタ

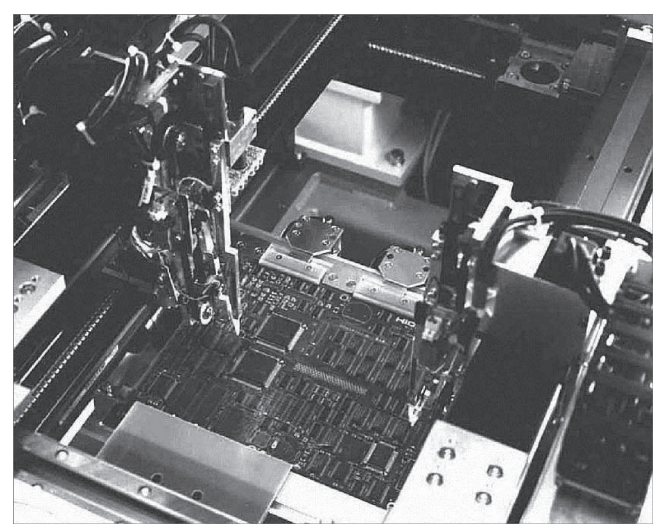

図 3. フライングプローブ方式のインサーキットテスタ
ローブが移動する構造となっている。このテス夕は，テス トジグが不要のため, 低コストでテストできる利点がある が, 数本のプローブではんだ付け部分の電気的なテストを 行うため, テストの時間が長くかかり，スループットが低 下するという問題がある。このため, 部品点数の少ない小 規模な基板や製造枚数の少ない基板に対して適用すると， テストジグ方式に比較してコストパフォーマンスが良くな る $^{2)}$

\subsection{2 バウンダリスキャンテスト ${ }^{1)}$}

バウンダリスキャン（Boundary Scan：以下 BS）テスト とはLSIのピンと内部論理との境界部（バウンダリ）にテ スト用の回路を組み込み, 内部論理と切り離してテスト用 に動作（スキャン）させることで，プリント配線板上に搭 載されている部品のはんだ付けが電気的に正しく行われて いることをテストする方法である。この方法はさらにLSI 内部論理の正当性までをも確認できる利点がある。

図 4 に, BS 回路を持つ LSI の構成を示す。BS 回路の基 本的な構成は, BS 回路の動作を制御する TAP (Test Access Port) と, LSI の入出力信号を記録する BS セルとで構成さ れている。BS 回路は, 外部からの信号 (TMS: Test Mode Select)によって, 通常動作モードとテストモードのどちら かに切り替えることができる。BS 回路が通常動作モードで あれば，外部からの入力信号は，LSI の内部論理にそのま ま伝播し通常の LSI 動作が行われる。しかし，BS 回路をテ ストモードにすると，BS セルと LSI 内部論理とを接続する 回路が切断され，BS セル同士を“一筆書き”でつなぐシフ 卜回路が動作するようになる。“一筆書き回路”を使うと, BS セルが記録した内容を TDO (Test Data Output) から順次 読み出したり，TDI (Test Data Input) から BS セルに任意の 内容を書き込んだりすることができるようになる。この結 果, LSI 外部から与えた信号が, LSI 内部論理の直前でどの ような信号になっているか，あるいは，LSI 内部論理が出
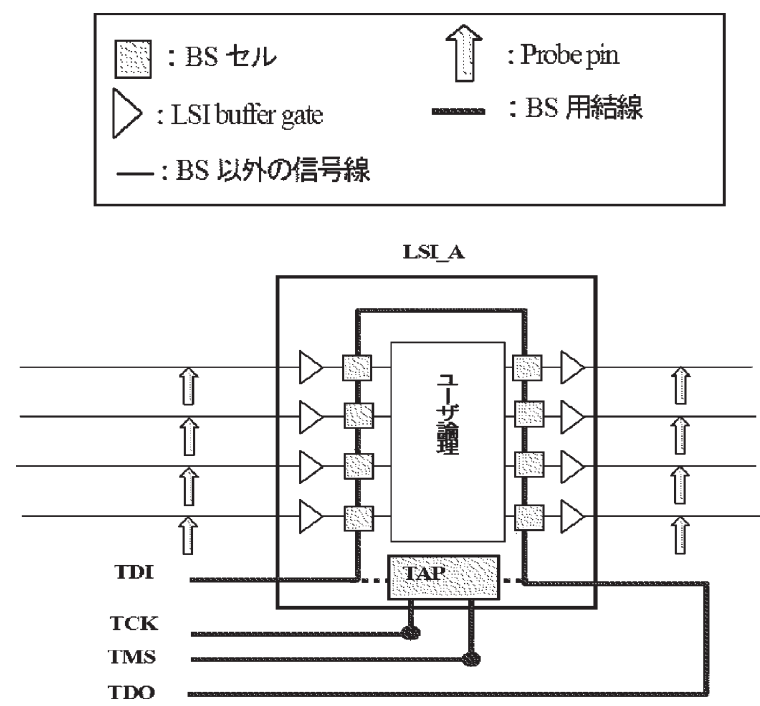

図 4.バウンダリテストの構成 
力した信号が，外部にどのように出力されるかがわかるよ うになる。

複数の LSI が搭載されている場合も一つの場合と同様の 方式を用いることでテストできる。バウンダリスキャンを 実行するためのテスタ上のソフトウェアには, 通常これら のテスト信号の生成機能や不良解析のためのツールが準備 されているためテストエンジニアがこれらを準備する必要 はない。

\subsubsection{FCT}

FCT では, かつては実装基板の入力端子からテスト信号 （テストパターン）を入力し, 出力端子からでる信号のパ ターンが所定通りかどうかを調べる手法が用いられていた が, LSI, アナログ部品, メモリなどが搭載されている今日 の実装基板ではこのようなテスト手法はほとんど適用でき ない。

そこで現在, 実装基板のインターコネクションテスト は，テストしたいがプロービング出来ないノードには配線 パターンの途中もしくは配線を延長してテストパッドを設 けるなどして，不完全ながらも FCT テストを行っている。 将来的には，ほとんど全てのノードにアクセスできるバウ ンダリスキャンテスト回路を実装基板に組み込む方向に向 かうと予想される。

\section{3. 製品ゾーンによる取組みの違い}

製品の製造工程に検査装置（工程）をどのように取り込 むかは, その製品の製造数と製品に要求される信頼度（品 質）によって異なる。ここでは下記の 3 ゾーンに分けて, 実装基板の信頼性を高めるための電気検査での取組みの違 いを説明する。

Aゾーン：(生産量が大, 信頼性が中) の代表的な製品と して, 携帯電話やパソコンなどの民生機器が挙げられる。 大量生産に対して最低限の検査で品質保証し, 高い歩留ま りを維持するためには, 各検査装置の連携が不可欠であ る。また最新の実装技術が要求される半導体やコネクタが 使用される機会も多く, ファインピッチへの対応も必要と

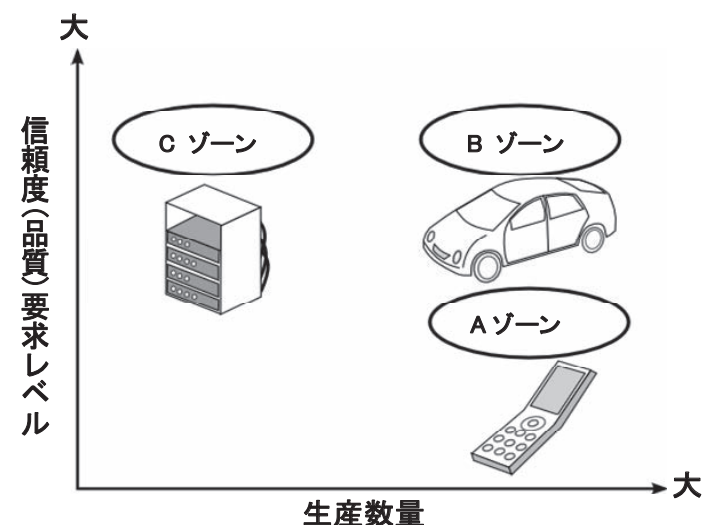

図 5. 生産数と信頼性によるゾーン分類
なる。

B ゾーン：生産量が多く，かつ高い信頼度レベルが求め られる製品群である。代表的な製品として，自動車が挙げ られる。高度な検查技術が求吼るのと同時に, 大量に 生産されるため高速な検查技術も求められる。また長期信 頼性を求められるので製造時の品質だけでなく, 経年劣化 に伴う実装不良に対しても考慮しておく必要がある。

Cゾーン：生産量は少ないが高信頼度を要求される製品 であり結果として高価な製品となる。

代表的な製品として，インフラストラクチャー系の設備 やデータセンタの中核に使われるコンピュータが挙げられ る。長期信頼性を求められるので製造時の品質だけでな く，検查に費用をかけても信頼度の高い製品を生み出すこ とが求められる ${ }^{2)}$ 。

\section{4. 各ゾーンでの電気検査の取り組み}

\subsection{A ゾーンにおける電気検査}

このゾーンでは大量の実装基板を高速に検査することが 求められている。

実装基板の電気検査では, 前述のようにインサーキット テスタとファンクションテスタが併用される場合が多い が，このゾーンの製品製造工程では，あまりにも厳密な検 查を行うと，製造時の検査コスト抢よび過剩検査による損 失が増大し，製品の競争力が損なわれかねない恐れがある。

このため, このゾーンの製品では検查時間の短縮および 検查装置にかかるコスト削減のため, 外観検查装置やX 線 検査装置と連携させて, 電気検査で確認する項目を絞り込 みコスト削減・時間短縮を図っている。またこのような対 応により, 検查工程の総合的な歩留まりの向上やテストカ バレッジの向上にも繋がっている。

このゾーンの検査では，インサーキットテスタとファン クションテスタを 1 台の検查装置に融合させて検査装置を 製作するという対応が多い。こうすることで検查時間のさ らなる短縮が可能となり，検查にかかるコストを抑制する ことができるようになった。

またこのゾーンの製品は他のゾーンよりもより実装密度 が高かったり, 部品の狭ピッチ化が進んでいるためコンタ クトプローブの接触方法についてもさまざまな改善や工夫 が見られる。

図 6 は, 実際のファンクションテス夕に使用している狭 ピッチコネクタへのコンタクトの事例である。

最小ピッチは, $0.3 \mathrm{~mm}$ までコンタクトが可能で, 各コネ クタの接触端子に直接コンタクトプローブを接触させてい るのが特徴である。

なお, 昨今, 部品や基板の小型化が進みスペースの限ら れた接触箇所へのピンコンタクトは, 技術的な限界を迎え つつある。 


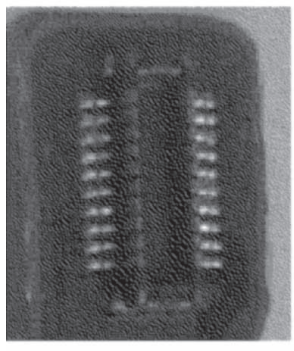

Board to Board コネクタ

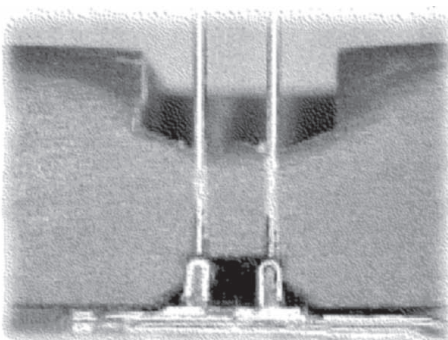

治具断面写真
図 6. 狭ピッチコンタクトの例

\subsection{B ゾーンにおける電気検査}

生産量が多く, かつ高い信頼レベルが求められる車載機 器関連を中心とする製品がこのゾーンの対象製品である。

車載機器としては, 不具合によって重大な事故に繋がる エンジン制御やブレーキ制御などの基板から，カーナビや イモビライザなどの基板まで多岐にわたる実装基板が使用 されている。

このゾーンの基板は，その使用環境から・激しい振動・ 高温下での使用・広範囲な周囲温度環境という使用条件が 必須となり, 要求される品質レベルは他のゾーンの実装基 板に比べてかなり高いといえる。

このため, 車載機器で使用されている実装基板に関し て, ほぼ全数の実装基板に対して外観検査・インサーキッ 卜検査抢よびファンクション検査が行われている。

具体的な特徵としてこのゾーンの検査では, コネクタピ ンへの直接のピンコンタクトが挙げられる。

図 7 は，実際に使用しているフイクスチャの例である。 実際のコネク夕を使用したコネクタの挿抜テスト，ゲー ジを利用した組込み高さの確認などが電気検查に組み込ま れ，コネク夕逆実装防止，ピン数違い防止，部品浮き防止 を行っている。

また，耐電流の大きいプローブを使用して，リークテス 卜を行う場合がある。図 8 はリークテストに使用する大電 流プローブの使用例である。

さらに，このゾーンでは実装基板の検査や評価を恒温槽 内 $\left(-50^{\circ}\right.$ から $\left.+120^{\circ}\right)$ で行う場合がある為, そのフィクス チャの材料には, 結露による錆が発生し難い部材, 耐熱性 のある部材の選定を行う必要がある。

こうした方法を採用し，Bゾーンでは実装基板の品質保 証に取り組んでいる。

\subsection{Cゾーンにおける電気検査}

高品質で生産量が少ない製品は, 医療システムや通信シ ステムなどの社会インフラシステムに関連するものが多 い。これらは，人命や経済活動などと密接に関係している ことから高い品質が要求される。特に近年では高齢化が進 む中, これらの社会インフラシステムに対する信頼性要求 はさらに高くなりつつある。

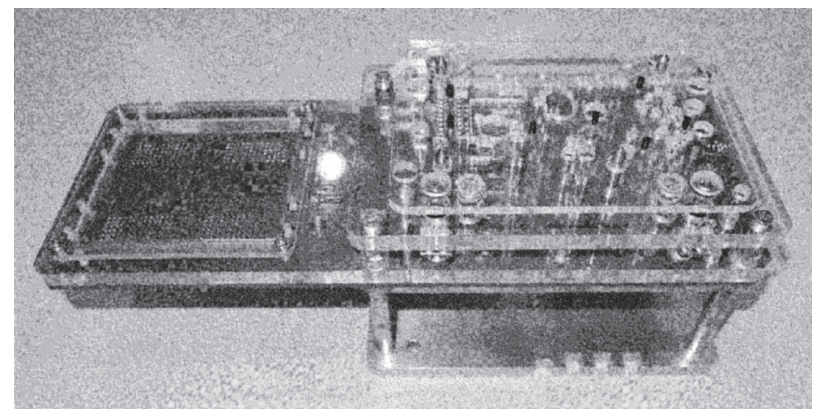

図 7. 上下からのコネクタへのピンコンタクトの例

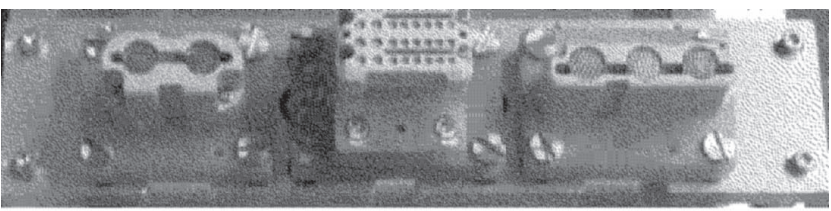

大電流向けブローブの使用

図 8. 大電流プローブ使用例

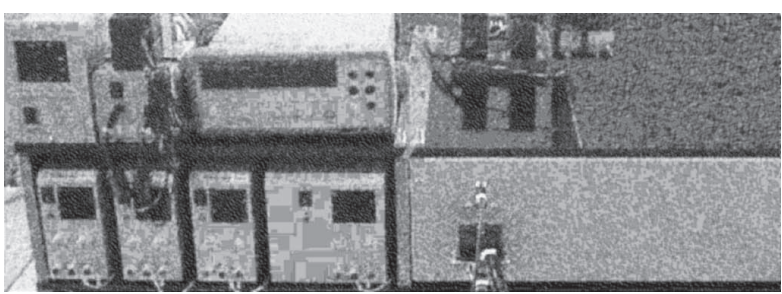

図 9. 計測器を接続する FCT

この様な社会情勢のもと装置メーカでは，高品質の製品 を短期間，低価格で顧客に供給することが強く要求されて いる。製品の性質としては高付加価值なものが多く，万一 不良品を摘出した場合には徹底した原因究明と対策が必須 である。

このゾーンの実装基板の検查においては，厳しい品質レ ベルを要求されていることから，製品によっては検査とい うよりも測定するという形態になる検查項目がある。その 場合は, 図 9 のように実際に校正された測定器を FCT に接 続して，測定值を確認するという方法がとられる場合があ る。

さらには，そうして測定したデータをログとして保管 し，トレーサビリティの管理を行うことが多い。

またこのような形態の FCT はその構成から，非常に高価 な装置になるため，製品開発ごとに新たな FCT を製作する ことはせず，あらかじめ後継機種での設備流用を考慮した 開発を行う場合が多い。

この領域の基板でも回路技術もその進化の度合いを増し て扔り, PWBA (Printed Wiring Board Assembly : 実装板) の高速・高密度・小型化が加速度的に進んでいる。近年で は部品内蔵基板も害用化が進み検査の難度はますます高く なっている。 


\section{5. まとめ}

実装基板の検査は, 生産工程内の外観検查・ $\mathrm{X}$ 線検查, 検査工程での ICT・FCT・BS テストなどさまざまなテスト 方法があるが, 対象となる製品により求められる品質レべ ルが異なる為，ニーズに合わせた経済的な検查が求められ る。

上流工程や設計段階でシミュレーションにより，テスト 手法の組み合わせ，テストカバレージ，コスト，メンテナ ンス性などを検討し, 最適な検査環境を構築することが重 要になってくる。

しかし，実際の製造現場ではどのような検査が自分たち の製品には最適な検査なのか, 必要以上の過剩品質には なっていないか，と言うことに対して自問自答を繰り返し ているのも事害である。

今後「見えない・触れない」製品の増加が予想されるな かで，設計部門と連携した DFT や各種試験を組み合わせた 総合的な品質保証技術が不可欠となる。

(2013.9.5- 受理)

\section{文献}

1) ケン・パーカー:“バウンダリスキャンハンドブック 第 3 版,”亀山修一監訳，青山社，2012.6

2) “2013 年度版日本実装技術ロードマップ,”電子情報技術産 業協会, pp. 338-405, 2013

3) 内山浩志 : “「検査の経済的尺度構築」に向けて,” エレクト ロニクス実装学会誌, Vol. 14, No. 2, pp. 103-108, 2011

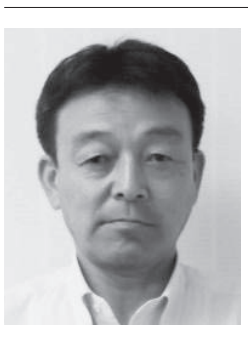

大久保今朝秀（おおくほ けさひで）

著者紹介

勤務先：日本フェンオール株式会社 八王子事業所 PWBA 第二営業部

日本フェンオール（株）において，プリント配線 板の実装および検査に約 15 年間従事

その経験を生かし 2008 年からは中国に赴任し,

EMS 先の QCD 全般の管理コントロール・調整に 携わってきた。

2013 年に帰任し現在はプリント基板実装の営業技 術として活動している。 